\title{
Development of a Biomedical Innovation Economy-Panama
}

\author{
Markus Dettenhofer ', Nora Hampl ${ }^{2}$
}

\begin{abstract}
In this study we consider the progress toward the development of innovation incubators within the Central American country of Panama. We attempt to identify the extent to which Panama, as a developing country with a small market size, has recognized the importance of technology and innovation in its efforts to build a sustainable economy. We examined the "Triple Helix" government-academia-industry model (Etzkowitz, 2008), and applied it to the bioscience sector, while also incorporating the role of foreign collaborators. By reinforcing and maintaining synergies among all stakeholders, while also concentrating resources in the areas of strengths and increasing R\&D expenditures, Panama could become a key regional player in the bioscience sector. Examples of cooperative research innovation are highlighted, and suggestions are made to enhance their commercialization potential.
\end{abstract}

Keywords: panama; bioscience; development; synergistic coordination.

\footnotetext{
${ }^{1}$ Department of Genetics, Harvard Medical School. 77 Avenue Louis Pasteur-NRB356. Boston, MA 02II5, USA. Tel: +|6174327578. E-mail: mdettenh@genetics.med.harvard.edu

${ }^{2}$ Davis Center and Department of Slavic Languages and Literatures, Harvard University, 12 Quincy Street-Barker Center \#340. Cambridge, MA 02138, USA. Tel: +|6174968I6I. E-mail: hampl@fas.harvard.edu
} 


\section{Introduction}

Independence gained from Gran Columbia was realized in 1903, but one could argue that the history of modern Panama started more recently. Two recent events significantly shaped present day Panama, the United States invasion of 1989, and the hand-over by the United States of the canal and with it billions of dollars worth of land and infrastructure (Pérez, 2000). The withdrawal of the remaining US military presence in the year 2000 allowed Panama to gain full sovereignty of its territories, and make independent decisions about the management of the Canal and the surrounding land. Today, Panama sees itself as an important logistical hub, keen on developing a foreign policy agenda with a number of global players. Even after the US-led invasion and disputes over military base rights, Panamanians retain a favorable view of the United States, and seek to strengthen their trading ties (Furlong, 2000). The relationship with Japan as the second largest trading partner is likely to continue as Panama looks to increase importation of Japanese technological goods. Other Asians countries such as China, Taiwan and Korea are increasing their level of investment and trade with Panama. The Colon Free Trade Zone is the largest of its kind in the Western Hemisphere, as it handles more than US\$14 billion in imports and re-exports each year.

Today's economy is largely based on transportation and logistics, financials, insurance, exportation of goods and services, and tourism comprising more than $80 \%$ of its productive output. Panama has recently enjoyed a period of substantial economic stability, with annual GDP growth of more than $8 \%$ over the last three years (U.S. Dept. of State, 2009). In an effort to build a diversified economy, a national strategy has been formulated to encourage science, technology and innovation. To this end, the government of Panama has prioritized science, technology and innovation for its long term growth. The presence of good infrastructure including transportation, electrical power generation, clean water, and internet connectivity within Panama City, and its central geographic location between North and South America, make it an attractive location for foreign investment. However, weaknesses have been acknowledged in the areas of innovation and higher education training (Cimoli, 2005). Many developing countries have recognized the importance of technology and innovation in their efforts to build sustainable economies. In this study we examined the potential opportunities for bioscience innovations and the barriers that might exist.

\section{Data Collection}

To get a more complete perspective of the innovative bioscience space in Panama, three main data sources were utilized for this study. We conducted personal interviews with individuals from the government, academia, technology park and private companies. Also, questionnaires were distributed regarding organizational interconnectivity and support for commercialization in Panama. Finally, traditional reference data were utilized to provide historical context and analysis within this space.

\section{Economic Agents}

Private companies or institutes that undertake research and development to generate products or services play an important role in a knowledge-based economy (Powers \& Powers, 1988). They serve not only to sell the goods and services of their labor force, but also to employ graduates of the universities. Locally or regionally generated diagnostic services, medicines and medical devices, as well as improvement in agricultural technologies, may present an attractive economic alternative to the importation of such products from large developed countries. For the bioscience sectors, health and agriculture-related products and services additionally contribute to the improvement in quality of life for the population (Cooke, 2007). The decision process for students in choosing an area of concentration is influenced not only by their intrinsic interests, but also by their exposure to external influences. The local presence of economic agents known to employ students impacts their choice of study.

ISSN: 07| 8-2724. (http://www.jotmi.org)

Journal of Technology Management \& Innoovation (@ Universidad Alberto Hurtado, Facultad de Economía y Negocios 
Although there are a hand-full of innovative bioscience companies in Panama, only a few are a result of solely Panamanian innovation efforts. Several Clinical Research Organizations (CROs) have operations in Panama and they include: Health Research International of the University of South Florida, Quintiles, a CRO based in North Carolina, and LaTAM Mo Clinical Research, a USColumbian venture. The Institute of Advanced Scientific Investigations and High Technology Services (INDICASAT) operates as a non-profit government research institute concentrating on medical-related local issues, such as infectious diseases. INDICASAT also serves as a regional CRO for pharmaceutical companies (eg. Glaxo Smith Kline), in human papilloma virus vaccines. The current trend towards establishment of clinical trials organizations within Panama is likely to continue due to the skilled medical personnel, a track record of previous FDA approved clinical trials, and reduced exposure to medication among the population as compared with developed countries.

In addition to CROs, several small international bioscience-focused companies have a presence in Panama. The Venezuela-Japanese-American joint-venture nanotech company, Nano Dispersion Technologies, develops dispersion fluids-breaking particles to a nanometric size. This technology may be applied to multiple industries ranging from oil and bio-fuels to cosmetics. With passage of the recent laws allowing research and therapeutic treatment using stem cells, two foreign companies have developed a presence within Panama. MediStem, which has facilities in the US and Costa Rica, focuses on discovery, development and commercialization of technologies related to adult stem cell extraction and manipulation for use in treating inflammatory and degenerative diseases. The Chinese company Beike, which also has operations in Thailand and Europe, has treated more than 2000 patients with umbilical cord stem cell injection principally for neurodegenerative diseases. Natural Control Corporation is an agriculture and insecticide company, which has been in existence for 40 years in Columbia, and now also has a presence in Panama. The business focus is on the improvement of output of mainly agricultural products, which have yielded revenues with the government as its principle client.

As bioscience innovation can be very capital intensive, it has the potential of not only large financial rewards but also the development of societal good (Cooke, 2007). This being the case, a large risk of failure exists for overly ambitious projects which are not gauged appropriately. Large multinational companies will take a calculated risk of entry based on a variety of factors such as tax incentives, trade tariffs, existing skilled labor force, infrastructure, and regional demand for their goods and services. Market entry for small organizations with little capital will need to consider these points, but work from the perspective of a short-term revenue model. The success of economic agents will rely on the ability of organizations to capitalize on local and regional strengths and build stakeholder interest in local and foreign markets (Brown \& Duguid, 2002; Gal, 2003). Building a local presence in addition to establishing foreign partnerships or collaborations with universities and private companies will reduce some risks inherent in starting of new ventures. Also, the importation of technical expertise, even on a temporary basis, will be critical to adequately train local students to become future employees. This will have the added advantage of rapid adaptation of innovative technologies and become a starting point for increased funding from international funding agencies. For a country such as Panama with a total market size of 3.3 million people, economic agents will be wise to pitch their goods and services to address local needs but also the global market. For example, services such as DNA-based disease diagnosis may find an adequate local market for their services, but nonrepeat use therapies may find the Panamanian market too small for sustainability. Nevertheless, even those bioscience innovation projects that consider the larger regional market and near-term revenue have the opportunity for sustainability.

A great promise for bioscience-related enterprise generation within Panama revolves around clinical trial ac-

ISSN: 07|8-2724. (http://www.jotmi.org)

Journal of Technology Management \& Innoovation @ Universidad Alberto Hurtado, Facultad de Economía y Negocios 
tivities. The establishment of a standardized health care facilities and low cost of medical care have encouraged CROs to enter emerging markets. Central and South America combined form a regional block with a total population of 562 million. From this perspective the region will become of greater importance to the pharmaceutical industry. From the standpoint of clinical trials, low cost is a driving force, as are the relative naive levels of exposure to medicines by the population at large (Shah, 2003; Getz, 2006). For countries such as Panama, the overall perception of clinical trial quality by regulatory agencies such as the FDA remains to be determined.

\section{Academics}

Emphasis in Panama has been placed on increasing the enrollment of students in university level education. From 1970 to 2000, university level education among scientific and technologically active employees has grown from $12 \%$ to $20 \%$ during this time frame (Villavicencio and Chiapa, 2006), yet only $0.5 \%$ of the economically active population is involved in science and technology as a profession. Traditionally, academic interests in biosciences have not been strong, with the exception of medicine and forensics. Given the recognized strengths of Panama's biologically-rich environment and the growing sector engaged in medical services, mechanisms are being put in place to increase the student population trained in these areas of specialization.

The University of Panama (UP) which was founded in 1935, has a student population of approximately 74,000 . UP being the largest university system in the country has developed a number of bioscience related centers, which serve as areas of study concentration. The UP offers a Master's degree program in biological sciences with four concentrations: 1) genetics and molecular biology, 2) zoology, 3) plants science, and 4) marine biology. At present UP does not offer a PhD program in biological sciences but instead sends promising students to conduct thesis research at the University of Granada in Spain. There is a clear recognition among the faculty of the importance of commercialization of discovery. UP scientists continue to conduct experimental analysis of plant extracts from the surrounding jungles for biological activities of therapeutic benefit. Funding has been granted through the NIH for these studies, and collaborations with US universities continue. Patent protection for these discoveries has primarily been granted through the United States Patent and Trademark Office. The General Office for Registration of Industrial Property (DIGERPI) handles local intellectual property issues and falls under the guidance of the Ministry of Commerce and Industry.

The UP in an effort to facilitate commercialization of discovery has newly created the office of Transference of Research Results (OTRI in Spanish) in the City of Knowledge. This office functions as a link between UP and private sector companies. In this arrangement the University offers guidance with respect to proper economic incentives for the scientists involved in advancing their discoveries to commercialization. Also, UP has organized and participated in several workshops on intellectual property and patents, and recently, it has set up a database containing information regarding patents and intellectual property to assist researchers.

Other institutions in Panama have developed programs in biosciences. The Technological University of Panama offers a biotechnology study program with applications to the agricultural industry.

\section{Government}

The ministry of science and technology (SENACYT) has taken a very proactive role in the encouragement and development of a knowledge-based sector. It is well recognized that the economic competitiveness of a nation is linked with knowledge development (Arocena \& Sutz, 2000). To this effect, SENACYT has coordinated the formulation of a National Strategic Plan for the Development of Science, Technology and Innovation for the years 2006-2010. The aim is to provide a framework to guide the growth of a knowledge-based sector in Panama with respect to an array of science-related in-

ISSN: 07I8-2724. (http://www.jotmi.org)

Journal of Technology Management \& Innoovation (@ Universidad Alberto Hurtado, Facultad de Economía y Negocios 
dustries. As for the biosciences, recommended steps of action have been brought forth and include the formation of a national bioscience commission to provide guidance and policy oversight with the aim of strengthening capacity in technology and human resources to support sustainable development. Additional recommendations include the formation of a funding agency for biosciences, the development of human resources to meet the science and technology demands of the country, and further development of a five-year plan to broaden research in biosciences.

To date, SENACYT has already incorporated a number of aspects of the Strategic Plan. Since 2004, SENACYT has funded 280 scholarships ranging from the Bachelors degree level through to the PhD and Post-doctoral level. Of these, approximately 150 were for doctoral or post-doctoral level studies in foreign universities. In 2008 alone, Panama has invested $\$ 8$ million in scholarships. Scientific funding has also been made available for research in areas including biosciences, agriculture, tourism, logistics and transportation through an open granting process that is reviewed by an international board, and where emphasis is being placed on collaborative efforts that tie into the strengths of the country. The Open Calls or grants are available to both public and private entities. SENACYT has directed over \$IOM in public funding toward projects and activities in innovation as well as R\&D where both the private and governmental sector have been involved in conjunction with international collaborators. Although government constitutes the largest domestic funding source, financing from foreign sources represented $71 \%$ of all R\&D spending in 2002 (OECD Paris, 2004). Additionally, the National Research System (Sistema Nacional de Investigacion-SNI) was created in December 14, 2007 (Law 54), with the objective of providing policy direction and promoting scientific and technological research through economic incentives.

The favorable Panamanian tax incentives, high-level of computer connectivity and strong economic growth imply that basic elements to encourage growth in tech- nological output are present. To this effect, the development of the Technology Park within the City of Knowledge lends itself for innovation clustering. The presence of international NGOs and collaborative education programs with Louisiana State University and Florida State University may be a base for capacity building. However, improvements are needed in local science education and research training, strengthening publicprivate collaborations, intellectual property filings and job creation.

As the operating budget for INDICASAT is supported by the government, it has several revenue-generating programs in place that consist of contracts or collaborative agreements with foreign universities or companies. One of INDICASAT's collaborations links efforts of the University of Panama and the Smithsonian Tropical Research Institute to prospect for biologically active factors from natural sources, which falls under the International Cooperative Biodiversity Groups (ICBG) program. Bioassays are used to test extracts for potential therapeutic relevance, such as inhibition of infectious disease replication or as anti-cancer agents. Further preclinical testing of extracts is performed in collaboration with universities in the United States. INDICASAT is staffed by Panamanians, as well as foreign scientists trained either in foreign or local universities.

The public health institution, Gorgas Commemorative Institute of Health Studies (Instituto Conmemorativo Gorgas de Estudios de la Salud: República de Panama), founded in 1921, performs scientific research in health, epidemiology, and environment. With a generous grant from the Global Fund, Gorgas is building a state-of-theart facility to help develop a biomedical training program and reference diagnostic laboratory for the region. Gorgas additionally collaborates with Johns Hopkins Medical International in the areas of HIV, women's health, and medical and public health education, as it trains local talent in biomedical, laboratory, clinical and epidemiologic research. In operation since 2006, the Hospital Punta Pacifica is currently being managed by Johns Hopkins Medicine International. Besides providing clini-

ISSN: 07| 8-2724. (http://www.jotmi.org)

Journal of Technology Management \& Innoovation (@ Universidad Alberto Hurtado, Facultad de Economía y Negocios 
cal and diagnostic care, it also offers training opportunities for physicians.

The Smithsonian Institute for Tropical Research (STRI), which is a US government agency based in Panama, is a world class research institute which focuses on evolutionary biology and ecology. Its involvement in basic ecological research and characterization of plant and animal species diversity, set the groundwork for the ICBG program mentioned above. This program has received international funding from the National Institutes of Health, the US National Science Foundation, and the US Department of Agriculture (Rosenthal and Katz, 2004; Kursar, 2007). The STRI, which employs approximately 40 permanent international staff scientists, conducts some of the ICBG research jointly with UP and INDICASAT.

\section{Synergistic Coordination}

To develop a knowledge-based bioscience sector in a small market such as Panama, a synergistic coordination among various stakeholders will be needed to strengthen the sector as a whole (Figure I). Sectors based on knowledge-driven innovation and commercialization of discoveries as a means of stimulating economic growth, have been characterized in the "Triple Helix" model (Etzkowitz, 2008). This model incorporates policydriven initiatives that promote the interaction between government, academia, and industry. The government of Panama plays a significant role in making available the regulatory guidance, infrastructure, and public financing for innovative projects. The greatest benefactors thus far have been academic and non-profit research institutes, but private companies with innovative programs may benefit as well. While Panamanian universities place emphasis on teaching, they are constrained with regard to pushing innovative research agendas forward. The importance of training students to become productive members of the knowledge-based labor force is of great interest when trying to encourage bioscience development to prosper (Wemmer, 1993). Companies can aid in this process by incorporating promising students into internship programs to prepare them for careers in the private sector. Because a majority of bioscience R\&Ddependent businesses have long cycles before they generate revenues, they tend to be initially dependent on private financing groups. A return on investment in bioscience innovation projects has traditionally come from buy-outs, stock exchange listings, or large-scale growth through sales of the organization's goods and services (Hall, 2002). When innovative enterprises seek private financing, two issues have to be addressed above all: a reasonable chance of success and a viable exit strategy for the investment. Once successful precedents are created on the market, financiers become more involved, and the sector will grow more rapidly. An increase in science capacity should also lead to job creation and generation of new products, which will ultimately serve the government's interests in growing the economy.

ISSN: 07I8-2724. (http://www.jotmi.org)

Journal of Technology Management \& Innoovation (@ Universidad Alberto Hurtado, Facultad de Economía y Negocios 


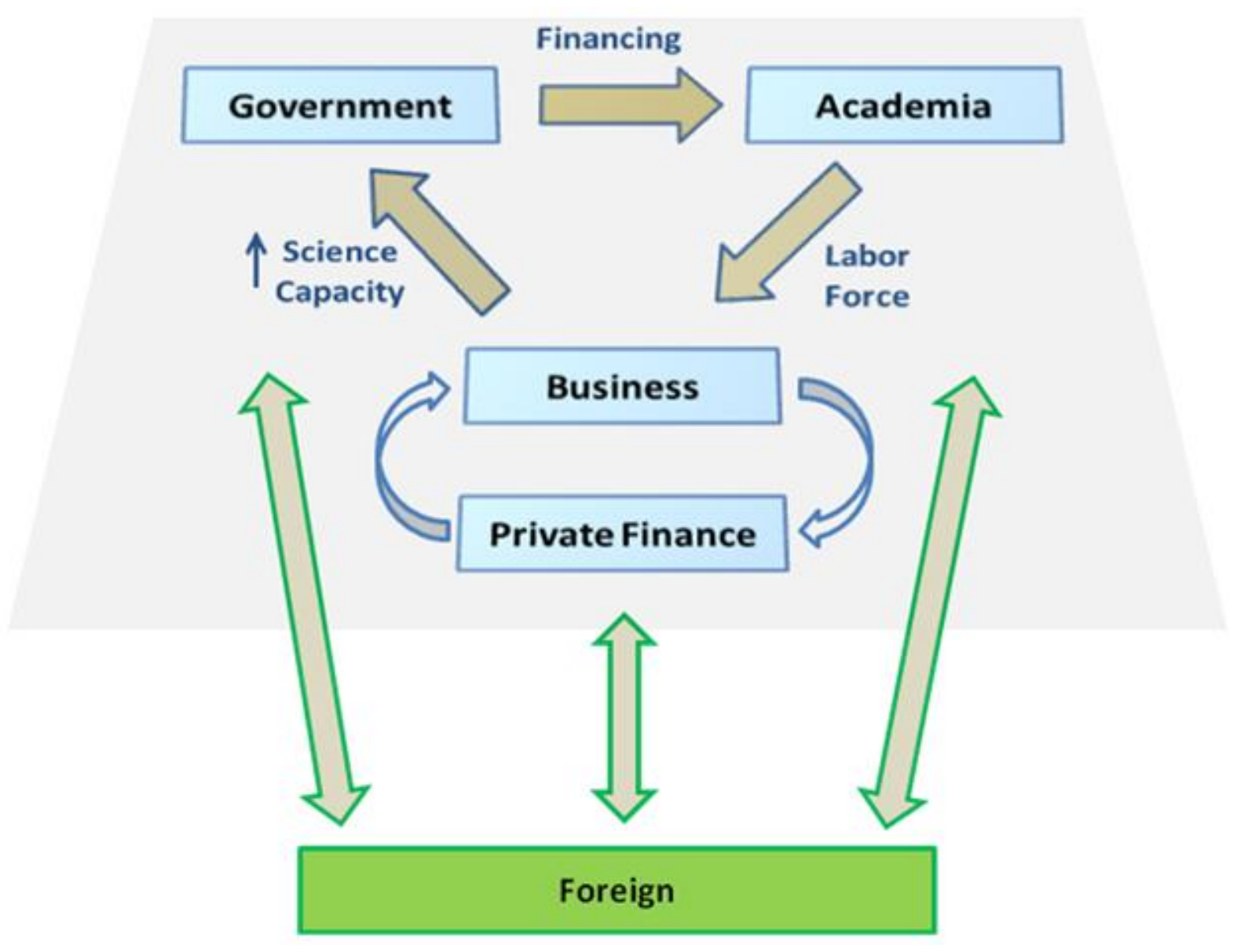

Figure I. Interdependence and strengthening of the bioscience innovation sector with foreign entities.

For smaller developing countries, developed foreign markets play an important role in the sustainability of sectors such as the biosciences, primarily because of their large customer base, but also because they can be a source of readily transferable technologies (OECD; Bologna, 2000). To date, the main strength of Panamanian biosciences has been in the sourcing of biologically diverse specimens and activities related to clinical research, which form a foundation for foreign entities to pursue future academic and business endeavors. Indeed, increased interests in global health on the part of universities from developed nations are being fueled by emerging funding sources such as the Bill \& Melinda Gates Foundation, or the Global Fund. Also, greater public interest in climate change concerns may lead to increased funding and more "North-South" collabora- tions on biodiversity projects (Porter, 2008). Incentives by local governments, such as grant availability and taxfree status for innovative economic projects, should help spur foreign involvement.

\section{Barriers}

For purposes of recommending a model for Panama where virtuous cycles of synergistic coordination are adapted, we recognize that all stakeholders need to have a vested interest in the effort (Etzkowitz, 2008). If expectations are not met by any one of the stakeholders involved, these linkages will deteriorate and the collaborative efforts will not be sustained over longer periods of time. In Panama, we have identified some weaknesses in the linking of local labor force with inno-

ISSN: 07|8-2724. (http://www.jotmi.org)

Journal of Technology Management \& Innoovation @ Universidad Alberto Hurtado, Facultad de Economía y Negocios 
vative enterprises, both local and foreign. Although there seems to be a growing number of qualified scientists, their ability to maintain a high-level of innovation through employment remains challenging. Although SENACYT has vastly invested in scholarships, the funding has gone in large part to cover graduate and postdoctoral training of students abroad. The creation of local jobs which utilize the innovative capacity in support of a qualified scientific labor force, is necessary when trying to either repatriate Panamanian scientists from abroad or retain them in Panama. Without the necessary domestic infrastructure and future employment opportunities, the risk of losing these newly trained scientists to foreign markets is very high. In this regard, we suggest a more significant investment in local academic research as an incentive to bring foreigntrained Panamanian scientists home. Equally important we consider the investment in local scientific training in the area of applied research, with the aim of creating new capacity for the development of bioscience-related products and services in the private sector.

Traditionally, academics from Latin America have felt a certain level of unease with applied research, questioning whether for-profit research is likely to compromise scientific integrity (Arocena \& Sutz, 2000). Although this sentiment is not universal (Bok, 2003), the perception of this division between pure and applied research acts as a barrier in the formation of cooperative relationships between universities and industries. When trying to create the synergy between the private sector and the academic setting, it is necessary that some academic researchers understand not only the path from inquiry to discovery, but also to commercialization (Etzkowitz, 2004). This knowledge and exposure may lead to a more seamless adaptation of products to the market. A balance among stakeholders can only be reached when a gradation of basic and applied research is performed in the universities and when it can be utilized by industrial partners.

To drive innovation in Panama, we found that more efforts need to be directed toward achieving a critical mass of qualified researchers and business leaders. According to the Global Competitiveness Index, Panama's level of capacity for innovation remains challenged. One of the identified weaknesses has been the relatively low availability of scientists and engineers within the population (2.3 for every 10,000 inhabitants, in Cimoli, 2005). By comparison, Costa Rica and Uruguay have had 3 and 5 times, respectively, as many individuals engaged in science and technology. Among the number of Panamanian scientists with appropriate training, only a few have dedicated themselves to research only. Faculty members at universities have been principally promoted through their teaching efforts, with little emphasis placed on research. Recognizing this weakness, SENACYT has invested $\$ 5$ million in 2007, and $\$ 8$ million in 2008 in scholarship programs for local talent to pursue their graduate and post-doctoral training, thus addressing one of the needs of the Panamanian innovation sector.

A knowledge-based sector that relies on biomedical advances must not only have qualified human resources, but also highly specialized equipment. The high cost of technically specialized equipment due to small market demand strains capacity building. In particular, reliance on equipment purchases through high income countries such as the United States drives the prices very high and does not allow for equal access to these resources. As distributors lack the incentive to enter the Panamanian market because of low demand, in the absence of competition, prices for equipment and supplies may be controlled by a sole distributor. Additionally, Panama's small market size currently contributes to inflated cost of equipment maintenance and repair due to a limited supply of qualified technical service personnel. Given the appropriate incentives, influx of new technologies will help in solving these shortages.

\section{Recommendations}

With the vast potential in biosciences, countries of small market size would be best served to examine their inherent strengths and build capacity around those areas (Brown \& Dugaid, 2002; Gal, 2003). Success of complex scientific endeavors relies on geographically concentrated technology platform building capabilities, whether in developed or developing countries (Mytelka, 2006). In Panama, two dominant bioscience areas are perceived

ISSN: 07I8-2724. (http://www.jotmi.org)

Journal of Technology Management \& Innoovation @ Universidad Alberto Hurtado, Facultad de Economía y Negocios 
to be the sector's strengths, biodiversity research and medical-related services. To expedite the formation of the bioscience innovation sector, emphasis should be placed on the synergistic coordination in these two areas, and resources should be concentrated on building and promoting these areas within a regional framework. Panama could leverage these strengths to deepen and extend the international network of collaborators and co-investigators, which would result in a temporary or long-term recruitment of technically skilled talent.

Mutually beneficial cooperation with foreign universities or economic agents is more likely achieved when there is a full awareness of opportunities present in the country (OECD; Bologna, 2000). In this study, we have highlighted some of the foreign bioscience companies that have gained presence in Panama. Further promotional campaigns are needed to bring attention to the positive attributes of Panama's developing knowledge-based sector. Enhanced interaction through scientific conference attendance or hosting of such conferences would increase international exposure and ultimately lead to more international collaborations. Sustained collaborations over time between students returning from abroad and their international host universities will foster a greater network of interactions.

The more clearly the competitive strengths of the country are articulated, the greater will be the involvement of foreign collaborators. As highlighted by Porter (1998), competition within industries is not restricted by national boundaries. Rather, the development of a sustainable knowledge-based industry must be globally competitive. Because of the already existing, highly specialized, scientific international work force readily relocating between developed countries for work opportunities, the challenge for the developing countries will be to present comparable work opportunities in order to attract such a qualified global work force. A successful precedent exists in Panama with projects conducted by the Smithsonian Institute for Tropical Research, and the International Cooperative Biodiversity Groups (ICBG), programs which have greatly appealed to international scientists working in the area of systems-related ecology, evolution, and biodiversity. Suc- cesses of similar programs are dependent on sustained funding together with a continued research interest on the part of international collaborators. With the internationally recognized importance of biodiversity protection (Beattie, 2005), we can anticipate a growing interest in one of Panama's competitive areas of research - bioprospecting. If the level of competitiveness is to increase, the level of R\&D spending as percentage of GDP has to be higher than what is has been (below $0.5 \%$ ). Financing thus far has been provided by the government and foreign sources (Cimoli, 2005). Robust knowledgebased economies devote as much as 3\% of their GDP to R\&D, which correlates with strong higher education enrollments (Arocena \& Sutz, 2000). For example, over the last 20 years, South Korea raised their level of financing for R\&D from $0.4 \%$ to $2.9 \%$ of the GDP, and correlatively, higher education levels increased from $10 \%$ to $60 \%$ during this time frame (Kim, 1993). The higher the R\&D spending as a percentage of GDP, the more likely it is that Panama will successfully develop a viable knowledge-based economy.

We can anticipate that a steadily increasing number of students attending universities and seeking scientific training abroad through SENACYT programs will positively impact the Panamanian knowledge base. In order to provide an environment for discovery and innovation, well equipped laboratory infrastructure as well as sources of funding for material supplies, have to be provided to ensure research completion, publication and patent filings. The perception that specialized research will not have the infrastructure or critical mass of human resources to make scientific advancements, will keep students from returning. As an alternative, the development of local programs providing final phase of scientific training for Panamanian students studying abroad may be a good way to ensure their return, thereby preventing some of the country's brain drain. The training processes could involve local supervisory scientists in coordination with international site scientists. The goal of these collaborations would be to frame alliance strategy, coupling research training with specific aims that focus on local strengths in the bioscience sector. Improved human resource capabilities and increased local research capacity will foster deeper

ISSN: 07I8-2724. (http://www.jotmi.org)

Journal of Technology Management \& Innoovation @ Universidad Alberto Hurtado, Facultad de Economía y Negocios 
interest of international academics and economic agents, and it may lead to the framing of alliance strategies between local experts and foreign companies.

In addition to academic-based training programs, bioscience specialization fields need to be strengthened by aligning companies in the sector to become the downstream employers for graduating students. In the case of Brazil, the initial build-up of the biotechnology sector concentrated heavily on generic drug production (Rezaie, 2008). Although Brazil produced a large number of trained researchers from its academic institutions, this potential labor force was not in great demand because the skill sets did not match private company interests (Marques, 2007). To avoid this pitfall, creating internships in the private sector would enhance the skill set of students, while at the same time, provide targeted training opportunities for a future labor force. Internships function to train and qualify students for the workforce, while providing companies with a screening mechanism for future employees.

We additionally found that one of the components of synergistic coordination, entrepreneurship with its social and economic contributions, is not widely pursued. Instead of developing and implementing new ideas, local firms are inclined to produce known products and use established processes. With the exception of foreign nationals living in Panama, we observed that creativity, autonomy, independence and ability to take risks, were lacking in people's assessment of their professional choices. Because trial and error are essential to innovation and to the creation of new ideas (Audretsch \& Thurik, 2000), we conclude that the culture of innovation is yet to be developed in Panama. Efforts to encourage entrepreneurship among local students through business education and training may spur such activity.

The current bioscience sector in Panama is very fragmented, with little interconnectivity and a few collaborations between private companies and universities. Enhancing specific target areas of the bioscience sector through the establishment of "Centers of Excellence" would result in concentration of human resources and specialized equipment. Active international promotion of the potential capabilities of these areas of strengths would serve to initiate international academic collaborations (OECD; Bologna, 2000), thus allowing for grant funding through international sources. In the area of commercialization, new product development and supply of services to business entities would lead to a further funding sustainability and exposure of scientists to for-profit firms. One specific area of opportunity exists in the growing presence of clinical trials in the region. Given the current health care environment in developed nations, drug trials are on the rise globally and increasing in Latin America (Shah, 2003; Getz, 2006). Regional clinical trials address health concerns of the local population, thereby linking the expertise and interest of local scientists and physicians. Currently, the clinical research organizations present in Panama have a relatively high level of employment of locally trained personnel and as such contribute to the building of human resource capacity. Efforts to develop capacities related to clinical trials and linking them to local training programs would further facilitate concentration of local talent.

In this report, we attempted to outline a model for capacity building in the bioscience sector for the country of Panama. The elements of infrastructure, human resources, knowledge resources, and capital are being addressed as they represent the foundation for sustainable growth. We utilized the "Triple Helix" or government-academia-industry model for enterprise formation (Etzkowitz, 2008), and applied it to the biosciences sector of Panama. Importantly, we find the involvement of foreign players to be critical for the development of a sector within a small market. Once formed, the increased bioscience capacity will benefit from greater international academic collaborations, in recognition of mutually beneficial strengths. Foreign collaborations encompassing commercialization processes are likely to incorporate locally trained scientists and thus make the sector more sustainable. Efficient transfer of technologies from developed countries through access to specialized equipment and foreign-trained scientists, such as seen in the ICBG program, will help establish strong research programs. The presence of companies involved in bioscience services and R\&D will provide further im- 
petus for young talent to pursue study in the biosciences. Taking into account all efforts to date, we conclude that Panama has actively begun to build on its strengths in the biosciences. Further efforts to coordinate the interests of policy makers, academics, and commercial companies, together with foreign collaborators will only accelerate this process. With concentration of resources in the areas of strengths and increased R\&D expenditures, Panama could become a key regional player in the bioscience sector.

\section{Acknowledgements}

We would like to thank Dr. Nicolas Ardito Barletta, Dr. Julio Escobar, and Dr. Roberto Tarte for helpful input during the early stages of this work. We also thank the many researchers and administrators of the University of Panama, INDICASAT, SENACYT, The City of Knowledge, and the Smithsonian Institute for Tropical Research for providing much of the current information for this study.

\section{Competing statement of interests}

The authors have declared no competing financial interest related to this work.

\section{References}

AROCENA, R. and Sutz, J. (2000). Interactive learning spaces and development problems, Druid Working Paper. http://www.druid.dk/wp/pdf files/00-13.pdf (accessed February 26, 2009).

AUDRETSCH, D. B., and Thurik, A. R. (2000). Capitalism and democracy in the 2 Ist Century: from the managed to the entrepreneurial economy. Journal of Evolutionary Economics 10, I-2, 17-34.

BEATTIE, A., Barthlott, W., Elisabetsky, E., Farrel, R., Kheng, C. T., Prance, I., Rosenthal, J., Simpson, D., Leakey, R., Wolfson, M., and ten Kate, K. (2005). New products and industries from biodiversity. In: Hassan, R., Scholes, R., Ash, N. (eds). Millennium ecosystem assessment, ecosystems and human well-being, vol. I. Island Press, Washington, D. C.
BOK, D. (2003). Universities in the marketplace. Princeton University Press, Princeton. Brown, J. S., and Duguid, P. (2002). Local knowledge. Management Learning 33, 4, 427-437.

CIMOLI, M., Primi, A. and Casalet, M. (2005). National strategic plan for the development of science, technology and innovation, 2006-2010. SENACYT, Republic of Panama.

COOKE, P. (2007). Growth Cultures: The global bioeconomy and its bioregions. Routledge, New York.

ETZKOWITZ, H. (2008). The Triple Helix: Universityindustry-government innovation in action. Routledge, New York.

ETZKOWITZ, H. (2004). The evolution of the entrepreneurial university. International Journal of Technology and Globalisation I, I, 64-77.

FURLONG, W. (2000). Panama, a nation apart: its foreign policy and its challenges. In Perez, O. J. (ed.) Postinvasion Panama-the challenges of democratization in the new world order. Lexington Books, Lanham, Maryland.

GAL, M. S. (2003). Competition policy for small market economies. Harvard University Press, Cambridge.

GETZ, K. A. (2006). CRO contribution to drug development is substantial and growing globally. Impact Report 8, I-4.

HALL, B. H. (2002). The Financing of Research and Development. Oxford Review of Economic Policy I8, 35-5I.

KIM, L. (1993). National systems of industrial innovation. Dynamics of capability building in Korea. In Nelson, R. (ed). National innovation systems. A comparative analysis, Oxford University Press, New York.

KUSAR, T. A., Caballero-George, C. C., Capson, T. L., Cubilla-Rios, L., Gerwick, W. H., Ibañez, A., Linington, R. G., McPhail, K. L., Ortega-Barría, E., Romero, L. I., and Coley, P. D. (2007). Linking biosprospecting with sustainable development and conservation: the Panama case. Biodiversity Conservation 10, Online.

ISSN: 07/8-2724. (http://www.jotmi.org)

Journal of Technology Management \& Innoovation @ Universidad Alberto Hurtado, Facultad de Economía y Negocios 
MARQUES, R. (2007). The Brazilian system of innovation in biotechnology: a preliminary study. Journal of Technology Management \& Innovation 2, 55-63.

MYTELKA, L. (2006). Pathways and policies to biopharmaceutical innovation systems in developing countries. Industry \& Innovation 13, 415-436.

Organization For Economic Co-Operation And Development. Conference for Ministers responsible for SMEs and Industry Ministers (OECD, Bologna, 2000). Enhancing the competitiveness of SMEs in the global economy: strategies and policies http://www.oecd.org/dataoecd//9/ 53/2012844.pdf (accessed April 20, 2009).

Organization For Economic Co-Operation And Development. OECD Main Science and Technology Indicators, 2004 Edition (OECD, Paris, 2004).

PÉREZ, O. J. (2000). Democratization and economic development: challenges and opportunities for the next century. In Perez, O. J. (ed.) Post-invasion Panama-the challenges of democratization in the new world order. Lexington Books, Lanham, Maryland.

PORTER, G., Bird, N., Kaur N., and Peskett, L. (2008). New Finance for Climate Change and the Environment. http://www.worldwildlife.org/what/howwedoit/conservat ionfinance/WWFBinaryitem 10912.pdf (accessed April 19, 2009).

PORTER, M. E. (1998). The competitive advance of nations. The Free Press. New York.

POWERS, D. R., Powers, M. F. (1988). Part one: making partnerships work: objectives, approaches, and strategies. In Powers, D. R., Powers, M. F., Betz, F., and Aslanian, C. B. (eds.) Higher education in partnership with industry. Jossey-Bass Inc., San Francisco.

REZAIE, R., Frew, S. E., Sammut, S. M., Maliakkal, M. R., Daar, A. S. and Singer, P. A. (2008). Brazil health biotech-fostering crosstalk between public and private sectors. Nature Biotechnology 26, 6, 627-644.

ROSENTHAL, J. P., and Katz, F. N. (2004). Natural products research partnerships with multiple objectives in global biodiversity hotspots: Nine years of the International Cooperative Biodiversity Groups Program. In: Bull, A. (ed) Microbial diversity and bioprospecting. ASM Press, Washington DC.

SHAH, S. (2003). Globalization of clinical research by the pharmaceutical industry. International Journal of Health Services 33, 29-36.

United States Department of State, Background Notes: Panama. (March 2009). http://www.state.gov/r/pa/ei/ bgn/2030.htm (accessed April 17, 2009).

VILLAVICENCIO, D. and Chiapa, A. (2006). http://portal.unesco.org/education/en/files/55577 (access December 12, 2008).

WEMMER, C., Rudran, R., Dallmeier, F. and Wilson, D. E. (1993). Training developing-country nationals is the critical ingredient to conserving global biodiversity. Bioscience 43, II, 762-767. 